\title{
CONOCIMIENTO Y PRÁCTICA DE LA HERBOLARIA EN EL ESTADO DE MÉXICO, PAUTAS HACIA LA SUSTENTABILIDAD
}

\section{KNOWLEDGE AND PRACTICE OF HERBALISM IN THE STATE OF MEXICO, GUIDELINES TOWARDS SUSTAINABILITY}

\author{
Georgina Gutiérrez-García ${ }^{1,2}$, Enrique Espinosa-Ayala ${ }^{3}$, Pedro Abel Hernández-García ${ }^{3}$, \\ Thelma Beatriz Pavón-Silva ${ }^{2}$, Ofelia Márquez-Molina ${ }^{3^{*}}$
}

\begin{abstract}
${ }^{1}$ Doctorante en Sustentabilidad para el Desarrollo. Centro de Estudios e Investigación en Desarrollo Sustentable de la Universidad Autónoma del Estado de México. Mariano Matamoros núm. 1007. Colonia Universidad. 50130. Toluca, estado de México. ${ }^{2}$ Unidad Académica Profesional Acolman, Universidad Autónoma del Estado de México. Camino de Caleros Num. 11. Colonia Ejido de Santa Catarina. 55875. Acolman, estado de México. México. (garcia.georgina@hotmail.com), (th.pavon@gmail.com). ${ }^{3}$ Centro Universitario UAEM Amecameca. Universidad Autónoma del Estado de México. Carretera Amecameca Ayapango Km. 2.5.56900. México, (enresaya1@hotmail.com), (pedro_abel@yahoo.com), (ofeliammolina@ yahoo.com).
\end{abstract}

\section{RESUMEN}

La herbolaria y la medicina tradicional en México son actividades persistentes en la población, las cuales se abordan desde perspectivas diversas, aunque existen pocos reportes que mencionen su sustentabilidad. El objetivo del estudio fue identificar y documentar el conocimiento y prácticas sustentables realizadas por los recolectores, productores y consumidores de plantas medicinales del oriente del estado de México. La hipótesis fue que el conocimiento transmitido intergeneracionalmente ha llevado a una práctica sustentable de la herbolaria. El método etnobotánico se utilizó para determinar la sustentabilidad del sistema. Entrevistas semiestructuradas se realizaron a actores claves que fueron adultos mayores, recolectores y productores de plantas medicinales. En la herbolaria local se identificaron 61 especies de plantas utilizadas, de las cuales 35 se recolectan o cultivan para su venta en el tianguis de Ozumba, estado de México. Los adultos mayores usan las plantas locales y refirieron otras 26 especies diferentes, de las cuales cinco las adquieren en comercios naturistas, de las restantes (21), su utilidad principal no es la medicinal: seis son de ornato, 13 se usan en la cocina y dos se consideran perennes silvestres. La herbolaria sigue presente en el oriente del estado de México, a través de un intercambio proactivo entre el productor recolector y los adultos mayores, quienes adquieren las plantas locales de temporada y favorecen la conservación de prácticas agrícolas amigables con el ambiente. La herbolaria es una práctica

* Autor para correspondencia * Author for correspondence. Recibido: mayo, 2020. Aprobado: julio, 2020.

Publicado como ARTICULO en Agrociencia 54: 1043-1058. 2020.
ABSTRACT

Herbalism and traditional medicine in Mexico are persistent activities in the population, both address diverse perspectives, although there are few reports mentioning the sustainability of such activities. The objective of the study was to identify and document the knowledge and sustainable practices carried out by the collectors, producers and consumers of medicinal plants in the east of the state of Mexico. The hypothesis was that the knowledge transmitted intergenerationally has led to a sustainable practice of herbalism. The ethnobotanical method was used to determine the sustainability of the system. Semistructured interviews were conducted with key actors who were older adults, collectors, and producers of medicinal plants. Plants of 61 species used were identified at the local herbalist market, 35 species are collected or grown for sale in the street market (tianguis) of Ozumba, state of Mexico. The older adults use the local plants and referred other 26 different species, of which five are acquired in naturalist stores, of the remaining (21), their main use is not medicinal: six are ornamental, 13 are used in cooking and two are considered wild perennials. Herbalism is still present in the east of the state of Mexico, through a proactive exchange between the harvesting producer and the elders, who acquire the local plants in season favoring the conservation of environmentally friendly agricultural practices. Herbalism is a sustainable practice thanks to the harvesting and production processes. Although it may be at risk due to the loss of intergenerational knowledge; as transmissibility decreases, the future of the activity is at risk. Other risks detected are of economic nature caused by the low prices of medicinal plants. 
sustentable gracias a los procesos de recolección y producción. Aunque puede estar en riesgo debido a la pérdida del conocimiento intergeneracional; ya que al disminuir la transmisibilidad se arriesga el futuro de la actividad. Otros riesgos detectados son económicos por los precios bajos de las plantas medicinales.

Palabras claves: conocimiento cultural, etnobotánica, sustentabilidad, herbolaria, uso tradicional.

\section{INTRODUCCIÓN}

$\mathrm{E}$ n culturas y países diversos la medicina tradicional es la fuente principal de atención sanitaria y en ocasiones la única. Su demanda se debe a que es próxima a los hogares, asequible y aceptada culturalmente (Andrade-Cetto y Heinrich, 2005). La Organización Mundial de la Salud (OMS) definió a la medicina tradicional como "el conjunto de conocimientos, capacidades y prácticas basados en las teorías, creencias y experiencias propias de culturas diferentes, bien sean explicables o no, utilizadas para mantener la salud y prevenir, diagnosticar, mejorar o tratar enfermedades físicas y mentales" (OMS, 2013).

La medicina tradicional considera a la herbolaria dentro de sus prácticas, la cual se basa en el empleo de plantas con fines medicinales y recreativos. En el caso de México se cuenta con la fusión de culturas diversas como las prehispánicas, la influencia de la colonización europea cuando se introdujeron especies nuevas que incluyeron algunas procedentes de Oriente medio e incluso Asia y Oceanía. Dicha fusión se ha perpetuado a través del tiempo y ha generado una tradición (Villarreal-Ibarra et al., 2014).

La herbolaria desde la etnobotánica (Martin, 2004) se estudia en el mundo (Parthiban et al., 2016; Cussy-Poma et al., 2017; Fernandes y Boff, 2017) y permite la identificación de especies locales. La Iniciativa Global para Sistemas Tradicionales de Salud mencionó que en 1997, cerca de 35000 especies de plantas se usaron en el mundo para propósitos médicos, pero solo 40 de estas especies se incorporaron a la medicina moderna (alópata). Tal situación no indica que las plantas no tengan potencial debido a que la mayor parte de dichos vegetales cuentan con metabolitos secundarios de interés farmacológico (OMS, 2019).

En México y especialmente la zona centro se cuenta con gran diversidad de plantas con uso
Key words: cultural knowledge, ethnobotany, sustainability, herbalism, traditional use.

\section{INTRODUCTION}

I $\mathrm{n}$ diverse cultures and countries traditional medicine is the main source of health care and sometimes it is the only one. Demand is due to its proximity to homes, affordability, and of cultural acceptance (Andrade-Cetto and Heinrich, 2005). The World Health Organization (WHO) defined traditional medicine as "the body of knowledge, skills and practices based on the theories, beliefs and experiences of different cultures, whether explainable or not, used to maintain health and to prevent, diagnose, improve or treat physical and mental illness" (WHO, 2013).

Traditional medicine considers herbalism within its practices, which is based on the use of plants for medicinal and recreational purposes. In the case of Mexico, we can count on the fusion of diverse cultures such as the pre-Hispanic ones, the influence of European colonization when new species were introduced, which included some from the Middle East and even Asia and Oceania. This fusion has persisted through time and it has generated a tradition (Villarreal-Ibarra et al., 2014).

Herbalism from an ethnobotanical point of view (Martín, 2004) is studied worldwide (Parthiban et al., 2016; Cussy-Poma et al., 2017; Fernandes and Boff, 2017) and allows the identification of local species. The Global Initiative for Traditional Health Systems mentioned that in 1997, about 35000 plant species were used worldwide for medical purposes, but only 40 of those species were incorporated into modern (allopathic) medicine. Such situation does not disregard that plants have potential because most of these plants have secondary metabolites of pharmacological interest (WHO, 2019).

In Mexico, especially in the central zone, there is a great diversity of plants with medicinal use, this is due to the agro-climatic conditions where the high zones near the great elevations, like the eastern zone of the state, stand out. The conservation of phytogeographic diversity in the eastern part of the state of Mexico is carried out by harvesting producers, who, based on empiricism and agro-ecological practices, favor the conservation of sociohistorical elements as generators 
medicinal, esto debido a las condiciones agroclimáticas donde destacan las zonas altas cercanas a las grandes elevaciones como la zona oriente del estado. La conservación de la diversidad fitogeográfica de la zona oriente del estado de México la realizan los productores recolectores, quienes a partir del empirismo y las prácticas agroecológicas favorecen la conservación de elementos sociohistóricos como generadores de cambio en un contexto de desarrollo (Astier et al., 2017).

La sustentabilidad como paradigma en constante cambio es aplicable en un campo extenso de acción y se dirige a alcanzar un estado dinámico entre la demanda de equidad, prosperidad y una calidad de vida mejor. No deja fuera a la ecología como eje rector, en el cual se relacionan la sociedad y la economía, en territorio y tiempo acotados el cual se puede aplicar en diferentes escalas, ya sea una familia, un proyecto o la industria (López, 2008).

El estudio de la sustentabilidad puede abordarse desde la triada: agroecológica, socio-territorial, económica (Toledo y Ortiz-Espejel, 2014), sin olvidar el tiempo (Leff, 2004). Una estructura alrededor de eventos significativos, sociales y económicos, con la medida de eventos externos (fenómenos geofísicos, ciclos ecológicos, procesos de degradación y regeneración de la naturaleza), y que se entreteje a través de la historia en las formas culturales de importancia en su modo de vida.

La agroecología se fundamenta en la conservación de elementos sociohistóricos, aunque externos a factores estrictamente ecológicos, pero que generan un cambio en el contexto en el cual se desarrollen (Astier et al., 2017). El objetivo de la agroecología es buscar sistemas agrícolas sostenibles (Gudynas, 2004) que nutran identidad y cultura, y refuercen la viabilidad económica de las zonas rurales (FAO, 2019). Al ser la herbolaria parte de un sistema agrícola que se mantiene basado en cultura y tradición, es viable su estudio desde la visión de la agroecología.

Con los antecedentes expuestos, el objetivo de este estudio fue identificar y documentar el conocimiento y prácticas agroecológicas realizadas por los recolectores, productores y consumidores de plantas medicinales al este del estado de México, bajo un enfoque sustentable. La hipótesis fue que el conocimiento transmitido intergeneracionalmente por los habitantes del oriente del estado de México ha llevado a una práctica sustentable de la herbolaria. of change in a development context (Astier et al., 2017).

Sustainability as a constantly changing paradigm is applicable in a wide field of action and is aimed at achieving a dynamic state between the demand for equity, prosperity, and a better quality of life. It does not leave ecology out as a guiding axis, in which society and economy are related in limited territory and time, which can be applied at different scales, whether it is a family, a project or industry (López, 2008).

The study of sustainability can be addressed from the triad: agro-ecological, socio-territorial, economics (Toledo and Ortiz-Espejel, 2014), without forgetting time (Leff, 2004). A structure around significant events, social and economic, with the measure of external events (geophysical phenomena, ecological cycles, processes of degradation and regeneration of nature), and that is interwoven through history in the cultural forms of importance in their way of life.

Agroecology is based on the conservation of sociohistorical elements, although external to strictly ecological factors, but which generate a change in the context in which they are developed (Astier et al., 2017). The objective of agroecology is to seek sustainable agricultural systems (Gudynas, 2004) that nurture identity and culture, and strengthen the economic viability of rural areas (FAO, 2019). Since herbalism is part of an agricultural system that is based on culture and tradition, it can be studied from the perspective of agroecology.

With all the above as background, the objective of this study was to identify and document the knowledge and agro-ecological practices carried out by collectors, producers, and consumers of medicinal plants in the east of the state of Mexico, under a sustainable approach. The hypothesis was that the knowledge transmitted intergenerationally by the inhabitants of the east of the state of Mexico has led to the sustainable practice of herbalism.

\section{MATERIALS AND METHODS}

\section{Study area}

The research was carried out in the eastern zone of the state of Mexico, in the municipalities of Amecameca de Juarez, Ozumba de Alzate and Ecatzingo de Hidalgo because the dynamics of production, collection and commercialization of medicinal 


\section{MATERIALES Y MÉTODOS}

\section{Zona de estudio}

La investigación se realizó en la zona oriente del estado de México en los municipios de Amecameca de Juárez, Ozumba de Alzate y Ecatzingo de Hidalgo debido a que en estos tres sitios se da la dinámica de producción, recolección y comercialización de plantas medicinales. Los municipios colindan con los volcanes Popocatépetl $(5426 \mathrm{~m})$ e Iztaccíhuatl $(5230 \mathrm{~m})$, dos de los más altos del Valle de México, estas altitudes propician la existencia de bosques de oyamel, pino y encino, así como vegetación secundaria arbustiva y herbácea, también denominada pradera de alta montaña (Gobierno del Estado de México, 2017).

Esta zona de estudio tiene tres áreas protegidas: el Parque Nacional Iztaccíhuatl y Popocatépetl, Parque Estatal Santuario del Agua y Forestal Manantial "El Salto de Atlautla-Ecatzingo" y el Parque Estatal Santuario del Agua y Forestal sin decreto "Salto de Amecameca", los cuales se ubican cerca del área volcánica (Gobierno del Estado de México, 2017). El promedio de precipitación anual es $1200 \mathrm{~mm}$ y la temperatura media varía de $12{ }^{\circ} \mathrm{C}$ a $18{ }^{\circ} \mathrm{C}$, aunque en invierno puede disminuir hasta $-3{ }^{\circ} \mathrm{C}$ La región presenta una variedad de tipos de suelo propicios para actividades diferentes como agrícolas, pecuarias y forestales, y padece un cambio intenso de uso de suelo por la expansión de la frontera urbana.

En el municipio de Ozumba de Alzate se ubica un tianguis del cual existen registros desde la época prehispánica, lugar donde se comercializan productos locales y provenientes del estado de Morelos. Este tianguis está dividido por secciones específicas y tiene un espacio para la herbolaria donde se comercializan principalmente especies vegetales cultivadas y recolectadas en la zona (Linares y Bye, 2009).

\section{Método etnobotánico}

En el estudio se aplicó el método etnobotánico (Martin, 2004), por medio de la técnica de entrevista semiestructurada y análisis del discurso a productores y recolectores de plantas medicinales (enfoque etnográfico), en las tres dimensiones de la sustentabilidad (Cuadro 1).

La entrevista se aplicó a 10 mujeres y un hombre por muestreo de voluntarios que se dedican a alguna de las actividades de producción, recolección y comercialización de plantas medicinales. Los entrevistados son originarios de los municipios de Amecameca de Juárez y de Ozumba de Alzate, en un lapso desde el 25 de junio de 2018 al 15 de marzo de 2019. Con lo anterior se identificó la interacción entre la agroecología, lo socio-territorial y la economía para determinar la sustentabilidad de la herbolaria. plants occur in these three sites. The municipalities border the Popocatepetl $(5426 \mathrm{~m})$ and Iztaccihuatl $(5230 \mathrm{~m})$ volcanoes, two of the highest in the Valley of Mexico, these altitudes favor the existence of fir, pine and oak forests, as well as secondary shrub and herbaceous vegetation, also called high mountain prairie (Government of the State of Mexico, 2017).

This area of study has three protected areas: Iztaccihuatl and Popocatepetl National Park, Water and Forest Sanctuary State Park "El Salto de Atlautla-Ecatzingo" and Parque estatal santuario del agua y forestal without decree "Salto de Amecameca", which are located near the volcanic area (Government of the State of Mexico, 2017). The average annual rainfall is $1200 \mathrm{~mm}$ and the average temperature varies from $12{ }^{\circ} \mathrm{C}$ to $18{ }^{\circ} \mathrm{C}$, although during winter it can drop to $-3^{\circ} \mathrm{C}$. The region has a variety of soil types suitable for different activities such as agriculture, livestock, and forestry, and suffers from an intense change in land use due to the expansion of the urbanistic border.

There is a street market, el tianguis, located in the municipality of Ozumba de Alzate, of which there are records from the preHispanic period; a place where local products from the state of Morelos are marketed. This tianguis is divided into specific sections and has a place for herbalism where mainly vegetable species grown and collected in the area are sold (Linares and Bye, 2009).

\section{Ethnobotanic method}

The ethnobotanical method was applied in this study (Martín, 2004), through the technique of semi-structured interview and discourse analysis of medicinal plant collectors and producers (ethnographic approach), in the three dimensions of sustainability (Table 1 ).

The interview was applied to 10 women and one man by sampling volunteers who are engaged in some of the activities of production, collection and marketing of medicinal plants. The interviewees are from the municipalities of Amecameca de Juárez and Ozumba de Alzate, and their interviews were conducted from June 25, 2018 to March 15, 2019. The interaction between agroecology, socio-territorial aspect and economy was identified to determine the sustainability of herbalism.

The variables studied to identify use and acceptance of medicinal plants were endemic plants and medicinal properties (agro-ecological dimension). A group of older adults was chosen because it was observed in the first approaches that they were the ones who acquired those plants more frequently.

A semi-structured interview was conducted for focus groups and by proposition sampling. The characteristics of the older adults were: 65 years or older, belonging to a municipal recreational group, indistinct sex, and having accepted to participate and 
Cuadro 1. Dimensiones y variables consideradas en la sustentabilidad de las plantas medicinales. Table 1. Dimensions and variables considered in the sustainability of medicinal plants.

\begin{tabular}{|c|c|c|}
\hline Dimensiones & Variables & Fuente \\
\hline Agroecológica & $\begin{array}{l}\text { Cultivo regulado, cultivos fuera del sitio, cambios en la efectividad de la planta, motivo por el } \\
\text { cual cultiva, origen de la producción, uso de fertilizantes, tiempo y resiliencias entre recolectas, } \\
\text { tipo de recolección, arranque o corte, crecimiento de nuevas especies, cambio de uso de suelo, } \\
\text { plantas endémicas, propiedades medicinales, áreas de recolección y cambios en el crecimiento } \\
\text { de las plantas locales } \\
\text { Extensión de tierra productiva destinada a plantas medicinales, policultivo, quema, tipo de } \\
\text { riego, agua para el cultivo, rotación de cultivos, control de plagas y uso de maquinaria para el } \\
\text { cultivo }\end{array}$ & Chen et al. (2016) \\
\hline Económica & $\begin{array}{l}\text { Destino de la producción, tipo de unidad de venta, costo por unidad, unidades/área productiva, } \\
\text { valor agregado por inclusión de otros materiales/transporte y cantidad/día de venta de las } \\
\text { plantas }\end{array}$ & Martínez (2005) \\
\hline Socio-territorial & $\begin{array}{l}\text { Actores sociales, principales colaboradores en la producción/recolección, edad, género, } \\
\text { escolaridad del recolector y actividades complementarias a la producción }\end{array}$ & Chen et al. (2016) \\
\hline
\end{tabular}

Las variables estudiadas para identificar uso y aceptación de las plantas medicinales fueron plantas endémicas y propiedades medicinales (dimensión agroecológica). Un grupo de adultos mayores se escogió porque se observó en los primeros acercamientos que ellos eran quienes las adquirían con mayor frecuencia.

Una entrevista semiestructurada se elaboró para grupos focales y por muestreo propositivo. Las características de los adultos mayores fueron: 65 años o más, pertenecer a un grupo recreativo municipal, sexo indistinto, aceptar participar y ser grabados en audio. Las entrevistas se realizaron de junio a septiembre de 2018. El total de participantes fue de 46, pertenecientes a los municipios de Amecameca de Juárez (17 personas), Tlalmanalco de Velázquez (12 personas) y Chalco de Díaz Covarrubias (17 personas).

\section{Consideraciones éticas}

El estudio se realizó de acuerdo con la Declaración de Helsinki y fue aprobado por el Comité de Ética del Centro Universitario de la Universidad Autónoma del Estado de México en Amecameca. El consentimiento informado se obtuvo de forma verbal de todos los participantes después de explicar el objetivo de la investigación y la confidencialidad de los datos proporcionados.

\section{RESULTADOS Y DISCUSIÓN}

Los productores recolectores preservan de forma empírica y racionalista el vulnerable equilibrio ambiental en la zona oriente del estado de México debido a los fenómenos naturales, como la constante actividad volcánica del Popocatépetl. Además, se enfrentan al cambio de uso de suelo que deja de being recorded on audio. The interviews were conducted from June to September 2018. The total number of participants was 46 , belonging to the municipalities of Amecameca de Juárez (17 individuals), Tlalmanalco de Velázquez (12 individuals) and Chalco de Díaz Covarrubias (17 individuals).

\section{Ethical considerations}

The study was conducted in accordance with the Declaration of Helsinki and was approved by the Ethics Committee of the Centro Universitario under the Universidad Autónoma del Estado de Mexico in Amecameca. Informed consent was obtained verbally from all participants after explaining the purpose of the research and the confidentiality of the data provided.

\section{RESULTS AND DISCUSSION}

The harvesting producers preserve, in an empirical and reasonable way, the vulnerable environmental balance in the eastern zone of the state of Mexico due to natural phenomena, such as the constant volcanic activity of the Popocatepetl volcano. In addition, they face the change in the use of soil that ceases to be agricultural or forestry and gets directed to residential use, which directly damages the production of medicinal plants endemic to the region.

The practice of herbalism is complementary and consequent to the cultivation of lands in the area, and is carried out by both men and women, who intervene at different moments of the process. For example, both men and women collect or cultivate 
ser agrícola o bosque y se dirige a uso habitacional lo cual perjudica de forma directa la producción de plantas medicinales endémicas de la región.

La práctica de la herbolaria es complementaria y consecuente a los cultivos del área, la realizan tanto hombres como mujeres, quienes intervienen en diferentes momentos del proceso. Por ejemplo, ambos recolectan o cultivan las plantas $y$, de manera principal, la mujer comercializa y sugiere al consumidor formas de aplicación de la herbolaria en el tianguis.

\section{Agroecológica}

Los productores recolectores entrevistados preservan las áreas protegidas y realizan recolección in situ de plantas endémicas. Las áreas se ubican en los montes o cerros (zonas boscosas aledañas a los volcanes) y permiten la resiliencia entre cortes, como señala la entrevistada: "...le corto por un lado y ya vuelve a retoñar no tarda mucho y depende de que luna lo corto, porque si lo corto en más o menos que está buena rápido retona, la luna buena es cuando tiene unos ocho dias de nacida, rápido retoña no es de mucho que tiene que estar así..." [P/R 1], "... si da fruta corto los ramilletes de los nisperos, y si no, pues le corto las hojas...” [P/R 2], “... le corto, asi queda la colita y de ahi vuelve a retoñar..." [P/R 4].

Para los cultivos ex situ toman las semillas de la planta medicinal del lugar de origen y las trasladan a las áreas de cultivo regulado (traspatio), espacio mantenido como policultivo con rotación "...la pasiflorina, me traje las semillas y aqui las sembré..." [P/R 1].

El agua destinada para la producción se obtiene de temporal "... en temporada de lluvia es cuando siembro más... (a veces siembra fuera de temporada) si, echándole tantitita agua nacen asi sin temporal..." [P/R 3]. Para los cultivos fuera de temporada utilizan agua potable de la red de distribución local "... de la llave... allá llega como ahorita llegó el agua..." [P/R 2], aunque esta actividad es limitada por la poca distribución de agua de la localidad "... raciono de la que almaceno en dos tinacos, $y$ de ahi tomo dos botes para regar los rábanos pero solo poquita...” [P/R 3], “...hasta hoy cayó el agua de la red de distribución local..." [P/R 10].

El tipo de fertilizante que utilizan los productores/ recolectores es el orgánico y lo que relatan es "...la basura (cáscaras de frutas y verduras) de la casa se riega en las plantas y cuando volteamos la tierra para sembrar the plants, but mainly women market them at the tianguis and suggest the consumer ways of applying herbalism.

\section{Agro-ecological}

The harvesting producers interviewed preserve the protected areas and carry out in situ collection of endemic plants. The areas are located in the mountains or hills (forested areas near volcanoes) and allow resilience between cuts, as the interviewee points out: "...I cut it on one side and it sprouts again, it does not take long and the cut depends on which moon is set, because if I cut it around a "good moon" it sprouts quickly, the good moon is when moon is about eight days old, it sprouts quickly, it is not long that plant has to remain like that...". P/R 1], "...if it gives fruit, I cut the branches of the medlar trees, and if not, I cut the leaves..." [P/R 2], "... so the tail (petiole) remains and from there, plant sprouts again...” P/R 4].

For ex situ cultivation, they take the seeds of the medicinal plant from the place of origin and move them to the areas of managed cultivation (backyard), a space maintained as polyculture with rotation "... the passionflower, I brought the seeds and I sowed them here...”. [P/R 1].

The water for production is obtained by rainfed "... the rainy season is when I sow more ... (sometimes out of season) yes, with a little water they are born out of rainy season ..." P/R 3]. For off-season crops, they use drinking water from the local distribution network "... we use tap water... there the water comes as now..." [P/R 2], although this activity is limited by the poor distribution of water in the area "... I ration the water that I store in two water tanks, from which I take two buckets to water the radishes, but only a little...". P/R 3], "...the water from the local distribution network came until today..." P/R 10].

The type of fertilizer used by the producers/ collectors is organic type and they report the following: "...the garbage (fruit and vegetable peels) from the house is spread on the plants and when we turn the soil over to plant we cover the garbage...". P/R 6], "...the manure from the horses, bulls, sheep, pigs (they fertilize once or twice a year) is used when it rains, and the "fat" (lixiviates) drains off, which maintains the plants along the dry season, they no longer need a lot maintenance...". and "... the yard is shared with my son's fattening bulls, he has little bull breeds, and he collects the manure and throws it on the plants..." $\mathrm{P} / \mathrm{R}$ 
ahi tapamos la basura...” [P/R 6], “...de los caballos, toros, borregos, cerdo (abona una o dos veces al año) se aprovecha cuando llueve, le escurre la grasita del abono, y en tiempo de secas de abi tienen mantenimiento, ya no necesitan mucho ni que les esté echando tanto..." [P/R 1] y "...es patio compartido con la engorda de toros que tiene mi hijo, él tiene sus toritos, y él junta el abono y les echa a las plantas ..." [P/R 2]. Por la dedicación que le tienen a sus cultivos no usan plaguicidas ni fertilizantes inorgánicos, “...no uso plaguicidas, deshierbo frecuentemente...” [P/R 1].

Cuando realizan el corte y recolección de las plantas, fuera de sitio, dejan partes de la planta que no son comerciales y evitan la quema "...nosotros no quemamos, al contrario lo tepachamos (corte y abandono de restos no útiles de la planta) para el abono, este temecate (tallos, raíces y zacate) mejor vengo y lo arranco y se lo doy a mis borreguitos lo comen o lo molemos cuando molemos zacate..." [P/R 1], esta estrategia evita la desertificación de la tierra “... la hojita que cae ahi queda para abonito..." [P/R 4], y la erosión hídrica de la zona "... la lluvia que cae fortalece a la tierra más..." [P/R 4].

La agroecología está basada en un conjunto de conocimientos y técnicas que se desarrollan a partir de los agricultores y sus procesos de experimentación. Por esta razón se enfatiza en la capacidad de las comunidades locales para experimentar, evaluar y ampliar su aptitud de innovación mediante la investigación de agricultor a agricultor utilizando herramientas del extensionismo horizontal (Altieri y Toledo, 2010).

Las prácticas agroecológicas son parte de la resistencia a la Revolución Verde que desde 1960 desplazó la valoración histórica, la co-evolutiva y la memoria cultural de los sistemas agrícolas locales, indígenas y tradicionales en México. La tendencia las llevó hacia la introducción de insumos y tecnologías para aumentar los rendimientos que respondieran a la demanda del mercado, y se redujo la dimensión socioeconómica a solo la económica (HernándezXolocotzi, 1985).

De acuerdo con los individuos entrevistados, la siembra y recolección de plantas medicinales son parte de la tradición y el conocimiento trasmitido intergeneracionalmente y su realización de traspatio permite que exista un enfoque ecológico mejor con una eficiencia económica baja, debido a que el consumo es local y no existe una demanda continua.
2]. Because of their dedication to their crops, they do not use pesticides or inorganic fertilizers, "...I do not use pesticides, as I made weeding by hand...” P/R 1].

When they cut and collect the plants, off-site, they leave parts of the plant that are not commercial and avoid burning "... we don't burn, on the contrary we cut it and abandon the remains of the plant ("tepachamos") the remains for compost, this temecate (this is, the stem, roots and grass) is pulled out and I give it as food to my little lambs or grind it when we grind grass... [P/R 1], this strategy "... the little leaf that falls there is left for natural decay...”. [P/R 4] prevents the desertification of the land, and the water erosion "... the falling rain strengthens the land more..." [P/R 4] of the area.

Agroecology is based on a set of knowledge and techniques that are developed from farmers and their experimental processes. For this reason, emphasis is made on the capacity of local communities to experiment, evaluate, and expand their ability for innovation through farmer-to-farmer research using horizontal extension tools (Altieri and Toledo, 2010).

Agro-ecological practices are part of the resistance to the Green Revolution, that since 1960, displaced the historical valuation, the co-evolutionary and cultural memory of local, indigenous and traditional agricultural systems in Mexico. The trend led them to introduce inputs and technologies to increase yields in response to market demand, and the socioeconomic dimension was reduced to an economic one (Hernández-Xolocotzi, 1985).

According to the individuals interviewed, the planting and harvesting of medicinal plants is part of the tradition and knowledge transmitted inter generationally and its implementation at backyards allows for a better ecological approach with low economic efficiency, because consumption is local and there is no continuous demand.

Collectors and producers mentioned 35 species of plants (endemic and adapted) that are used as medicinal plants (Table 2). Of these, 17 are collected on the slopes of volcanoes, nine are grown in backyards due to their properties and for the remaining nine, both activities are carried out, depending on the season.

\section{Socio-territorial}

In the case of the only male producer-collector interviewed, he carries out the process of collecting, 
Los productores recolectores mencionaron 35 especies de plantas (endémicas y adaptadas) que se usan como plantas medicinales (Cuadro 2). De éstas, 17 se recolectan en las laderas de los volcanes, nueve se cultivan en sus propiedades en traspatio y para las nueve restantes se realizan ambas actividades, lo cual depende de la temporada.

\section{Socio-territorial}

En el caso del único hombre productor recolector entrevistado, él realiza el proceso de recolección, venta y recomendaciones de uso de las plantas medicinales sin ayuda. Por el contrario, las mujeres tienen colaboración de los integrantes de la familia nuclear que pueden ser hijos o esposo o ambos. Los entrevistados se encuentran en un intervalo de edad de 50 a 78 años, con un nivel de escolaridad de secundaria.

La comercialización de plantas medicinales es una práctica complementaria a los ingresos económicos familiares porque la agricultura es la base de la economía familiar "...también sembramos maiz y frijol en otros terrenos que tenemos..." [P/R 2], la producción agrícola es para autoconsumo y el excedente se comercializa "...sembramos frijol y maiz para comer en el año...” [P/R 1].

Las productoras recolectoras mencionan que por la edad son dependientes económicos de sus hijos y ellos les permiten sembrar sus plantas en el traspatio y comercializarlas "...para tener un dinerito extra para mi..." [P/R 11], “...como vivo con mi hijo y mi nue$\mathrm{ra}$, ellos me dejan vivir con ellos, y me dan permiso de sembrar mis plantitas...” [P/R 10], “...para que me mantenga, yo estoy solita, nada más tengo un hijo pero ya se casó..." [P/R 8].

El tianguis de Ozumba surte de plantas medicinales al mercado Sonora de la Ciudad de México, lo cual ha generado nuevas necesidades en el productor recolector para satisfacer las exigencias del intermediario. Según Linares y Bye (2009) pueden agruparse en tres: el cultivo de plantas que no son endémicas, el cultivo de plantas que solo se recolectaban para uso local o familiar y la ampliación de relaciones sociales basadas en compadrazgo.

Los productores recolectores son originarios del municipio donde actualmente habitan, lo que ha generado una conciencia de arraigo a su localidad pues se perciben dentro del contexto histórico-ambiental “...me crecieron y crecieron mis hijos...” [P/R 9], “...mi esposo y yo somos de aqui y pues aqui nos quedamos, en selling, and recommending the use of the medicinal plants without assistance. In contrast, women are assisted by members of the nuclear family who may be children or husbands or both. The interviewees are in an age range of 50 to 78 years old, with a high school education level.

The commercialization of medicinal plants is a complementary practice to family income because agriculture is the basis of the family economy "... we also plant corn and beans on other land that we have...". [P/R 2], agricultural production is for selfconsumption and the surplus is marketed "...we plant beans and corn to eat during the year...”. P/R 1].

The female harvesters mention that because of their age they are economically dependent on their children and they allow them to plant their plants in the backyard and market them "...to have a little extra money for me...". P/R 11], "...as I live with my son and daughter-in-law, they let me live with them, and they let me sow my plants..." [P/R 10], “...to support me, I am alone, I only have a child, but he is already married...” P/R 8].

Ozumba's street market (tianguis) supplies medicinal plants to the Sonora market in Mexico City, which has generated new needs in the harvesting producer to satisfy the demands of the intermediary. According to Linares and Bye (2009) they can be grouped into three: the cultivation of non-endemic plants, the cultivation of plants that were only collected for local or family use, and the expansion of social relations based on relatives.

The harvesting producers are originally from the municipality where they currently live, which has generated an awareness of their roots in their locality, since they are perceived within the historicalenvironmental context "...I grew up here and so did my children...". My husband and I were born here and we stayed here in the village with our family. P/R 5]. This rooting has led them to try to maintain a balance between society and the environment.

\section{Economic}

The presentation of their plants comes in bunches for their marketing. These are calculated by the amount contained inside a hand, for wholesale: “...I don't like to make my bunches that way, I like them to be fair sized (pointing out the circular space between the thumbs and indexes of both hands), of holy leaf, at least about 25 leaves, then I take them to Ozumba or 
Cuadro 2. Características de las plantas medicinales que se usan en la zona de los volcanes. Table 2. Characteristics of medicinal plants that are used in the volcanoes area.

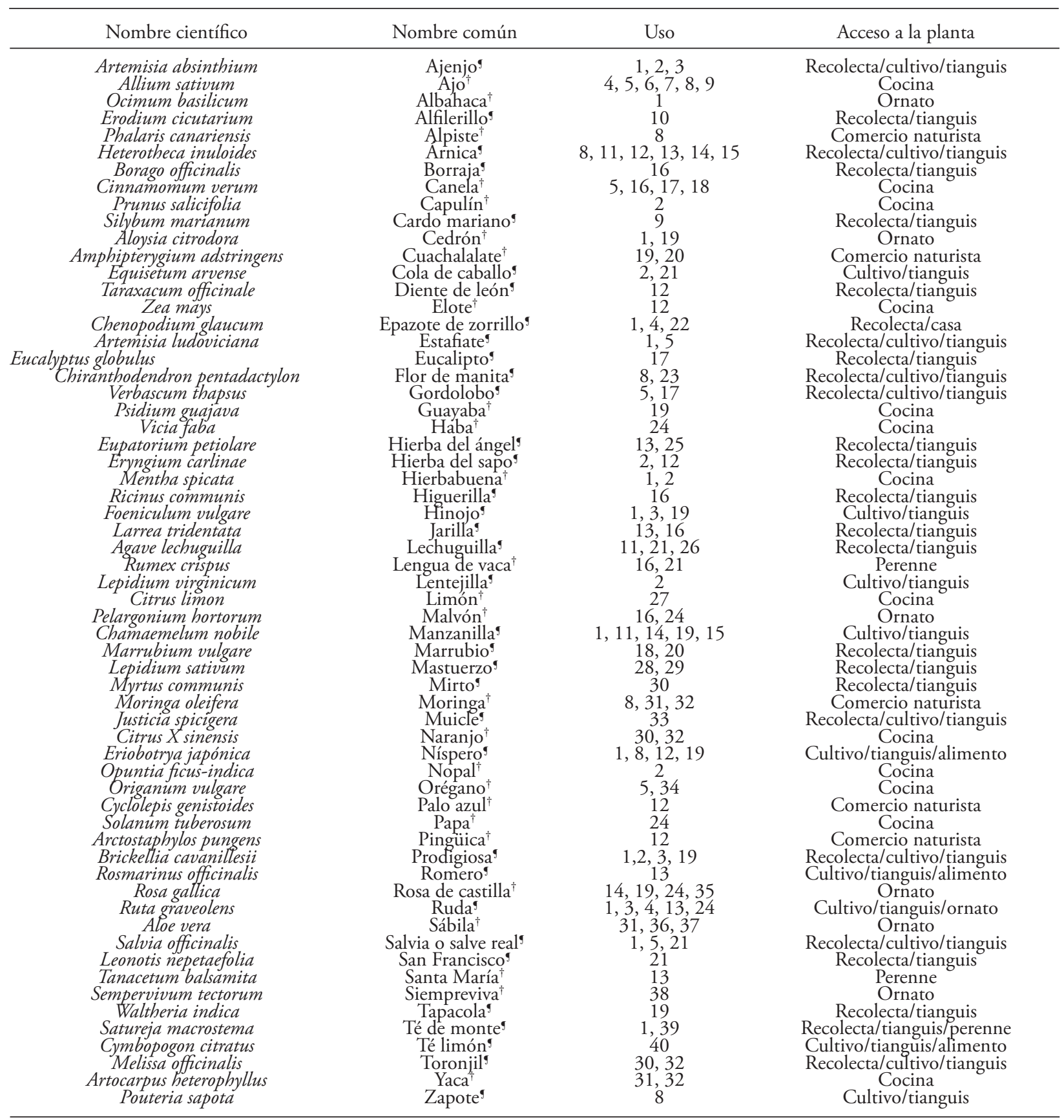

Uso: 1 = dolor estomacal; $2=$ hipoglucemiante; $3=$ "enojos" o "corajes"; $4=$ antihelmíntico; $5=$ antitusivo; $6=$ colecistitis; 7 = disentería; $8=$ presión arterial; $9=$ anticancerígeno; $10=$ herpes bucal; $11=$ antiséptico; $12=$ enfermedades renales; $13=$ baños para parturientas; $14=$ lavado oftálmico; $15=$ antiinflamatorio ocular; $16=$ antipirético; $17=$ enfermedades respiratorias; $18=$ hepatitis, $19=$ antidiarreico, $20=$ gastritis; 21 =antiinflamatorio; $22=$ amibiasis; $23=$ enfermedades cardiovasculares; $24=$ cefaleas; $25=$ "empacho"; 26= dolor de riñones, $27=$ resfriado común, $28=$ orzuelos; 29= dermatitis solar hipocromiante; 30= insomnio; $31=$ colitis; $32=$ ansiolítico; 33= anemia; $34=$ dolores menstruales; 35 = purgante; $36=$ acné; $37=$ amigdalitis, $38=$ carnosidades oftálmicas, $39=$ "limpias", 40= té recreativo; ‘: mencionada por el adulto mayor; "=mencionada por el productor/recolector y el adulto mayor. * Use: $1=$ stomach pain; $2=$ hypoglycemic; $3=$ "upsetting" or "anger"; $4=$ anthelmintic; $5=$ antitussive; $6=$ cholecystitis; $7=$ dysentery; $8=$ blood pressure; $9=$ anticarcinogenic; $10=$ oral herpes; $11=$ antiseptic; $12=$ renal diseases; $13=$ post birthing baths; $14=$ ophthalmic washing; $15=$ ocular anti-inflammatory; $16=$ antipyretic; $17=$ respiratory diseases; $18=$ hepatitis; $19=$ antidiarrheal; $20=$ gastritis; $21=$ anti-inflammatory; $22=$ amebiasis; $23=$ cardiovascular diseases; $24=$ headaches; $25=$ indigestion ("empacho"); 26= kidney pain; $27=$ common cold; $28=$ sties; $29=$ hypochromial solar dermatitis; $30=$ insomnia; 31= colitis; 32= anxiolytic; 33= anemia; 34= menstrual cramps; 35= purgative; 36= acne; 37= tonsillitis; 38= ophthalmic pimples; $39=$ distress-relieving baths ("limpias"); $40=$ recreational tea; ${ }^{\dagger}=$ mentioned by the older adult; " $=$ mentioned by the producer, collector and another older adult. 
el pueblo con nuestra familia..." [P/R 5]. Este arraigo los ha llevado a tratar de mantener un balance entre la sociedad y el ambiente.

\section{Económica}

La presentación en que comercializan sus plantas es en manojos. Estos los calculan por la cantidad contenida dentro de las manos, para la venta al mayoreo "....no me gusta hacer mis manojitos así, me gusta que estén más o menos regularcitos (señala el espacio circular comprendido entre los pulgares e índices de ambas manos) de hoja santa minimo unas 25 hojas, ya ve que luego las llevo a Ozumba o para mi sobrina, pero no me gusta que mis manojos estén chiquitos, sino más o menos regulares cuando lo vendo..." [P/R 8]. Para la venta al menudeo cambia la medida "...le calculo que tanto el manojo (señala con las manos y hace un círculo entre pulgar e índice)" [P/R 9].

$\mathrm{El}$ productor recolector menciona que el consumidor prefiere las plantas frescas, por eso la recolección se realiza un día antes de la comercialización, algunas plantas se introducen en recipientes con agua para mantener y conservar la frescura.

El precio puede variar, ya que si es mayoreo regularmente es establecido por el intermediario, pero no está alejado del precio en que se oferta en el tianguis “...nosotras pedimos más o menos y lo que nos ofrezcan...asi lo vendemos..." [P/R 3], "...ella (intermediario) me los paga un poquito más, (¿el intermediario es quien determina la paga?) no, porque más o menos sé el precio al que están en Ozumba y mínimo a ese precio que me pague, que ella ya lo vaya a vender al (Mercado de) Sonora..." [P/R 1].

En la venta al menudeo el precio es establecido por el vendedor "...por ejemplo a 10 o 12 (pesos) cuando se puede, si hay, si no (en temporada de secas) ahi como se pueda, como venga (el cliente) ...lo más que les pido es a 15 (pesos), lo que ofrezca..." [P/R 4].

Los productores recolectores no consideran los gastos extras que les generan los insumos necesarios para transportar y comercializar sus plantas, pues la inversión inicial es mínima comparada con la ganancia que les genera "...si compro lazo (para vender en Ozumba), pues me voy en el pesero o como ahora que estuve llevando chayote como que me conviene otro poquito más porque ya llevo más cositas... y tomo un coche..." [P/R 9].

La demanda del consumidor puede ser cubierta por plantas medicinales en fresco o en seco, lo cual to my niece, I don't like my bunches to be small when I sell them..." P/R 8]. For retail sale, the measurement changes"...I calculate the size of the bunch (pointing with the hands and making a circle between thumb and index)" [P/R 9].

The collector and producer mentions that the consumer prefers fresh plants, that is why the harvesting is made one day before commercialization, some plants are introduced in containers with water to maintain and preserve the freshness.

The price may vary, since it is a regular wholesale, so the price is established by the intermediary, but it is not far from the price offered in the tianguis "...we do not ask for much more than what they offer us... is how we sell..." She (the intermediary) pays me a little more, (does the intermediary determine the payment?) no, because I know more or less the price at which they are sold in Ozumba and at least that price she should pay, let her sell at the price she wants in the Sonora market... (at Mexico City)" [P/R 1].

In retail sales, the price is set by the seller "...for example 10 or 12 (MXN pesos; 0.49 USD) when possible, if there is product, if not (in dry season), either way, whatever comes (the customer) ... the most I ask is 15 (MXN pesos; 0.73 USD), whatever the client offers...". [P/R 4].

The collectors and producers do not consider the extra expenses generated by the inputs needed to transport and market their plants, since the initial investment is minimal compared to the profit generated "...if I buy a rope (sold in Ozumba), I take the bus or a cab because I can carry more things, like when I was carrying chayote (Sechium spp.), cab is more convenient...”. [P/R 9].

Consumer demand can be met by fresh or dry medicinal plants, which allows year-round availability, and producers collectors to maintain a delicate balance between the socio-territorial and the environmental, by allowing the plant to have periods for resilience.

The sale of medicinal plants by producers and collectors involves the knowledge of the uses that have been transmitted to them, not only the activity of buying and selling, some examples are: “...for cancer, the Santa Maria flower...sells for 25 (MXN pesos; 1.10 USD) the little bunch...; for strengthening of the blood, the muicle; for the fever, the borraja... 15 (MXN pesos; 0.73 USD), so take them with you...". $\mathrm{P} / \mathrm{R} 11]$; "... if you can't sleep, the myrtle is the solution, you take a bath with it and if you don't want to take 
permite disponibilidad todo el año, y que los productores recolectores mantengan un equilibrio delicado entre lo socioterritorial y lo ambiental, al permitir que la planta tenga periodos para resiliencia.

La venta de las plantas medicinales por los productores recolectores involucra el conocimiento de los usos que les han sido trasmitidos, no únicamente la actividad de compra venta, algunos ejemplos son “...para el cáncer, el cardo mariano... de a 25 (pesos) el manojito...; fortalecimiento de la sangre, el muicle, la temperatura, la borraja...estos de a 15 (pesos) para que se los lleve...” [P/R 11]; “...el mirto es si no puede usted dormir, se baña usted con él y si no se quiere bañar se pone debajo de la almohada si es que no puede dormir...el manojo de a 20 (pesos) por que están frescos...” [P/R 5]; “...jarilla, es para cuando los niños tienen temperatura...(cuánto cuesta) de a 15 (pesos) el manojito, ya ve que esta gordito, trae bastantito..." [P/R 3]; “...es prodigiosa, para cuando hace corajes... de a 10 (pesos) el manojito" [P/R 6]; “...esta es salve real para el dolor de estómago...si que lo puede llevar y ponerlo a secar y seco le sirve..." [P/R 7]

El conocimiento no es homogéneo, y es posible encontrar diferencias en las recomendaciones, “... Árnica que para las heridas, el marrubio que para la hepatitis... (el precio depende de la temporada) ahorita se la doy a 15 (pesos)...” [P/R 10]; “...el marrubio, para la gastritis... estafiate y el hinojo son buenos para el dolor de estómago...(¿cuánto cuestan?) 15 pesos cualquiera..." [P/R 8]. Todos los usos mencionados por los productores recolectores (Cuadro 2) forman parte de sus discursos de venta.

La pobreza rural conduce con frecuencia a estrategias desesperadas para la sobrevivencia en el intento de satisfacer las necesidades básicas a corto plazo, mientras que la sustentabilidad es a largo plazo. Por lo que debería de existir una revaloración de la agricultura dentro de la economía nacional y favorecer estrategias como la reforma del comercio internacional, la integración regional económica y la urbanización que conducirían a la reubicación de la agricultura y a una reestructuración de la producción agrícola (Gutiérrez et al., 2008).

\section{Uso y consumo de plantas endémicas y propieda- des medicinales}

Los adultos mayores (consumidores) mencionaron el uso de 61 especies de plantas medicinales, de a bath you put it under your pillow... the bunch is 20 (MXN pesos; 1 USD) because they are fresh..." [P/R 5];" jarilla is for kids with fever (how much does it cost?), 15 (MXN pesos; 0.73 USD) a bunch, you can see that this bunch looks fat here, it has quite a lot...". This is miracoulous (prodigiosa), for you to keep calm when it comes to anger.. 10 (MXN pesos; 0.49 USD) a bunch" [P/R 6]; "...this is the real salvation for the stomach ache...you can take it and put it to dry and it is good for you... [P/R 7].

The knowledge is not homogeneous, and it is possible to find differences in the recommendations, “... They say Arnica for wounds, marrubio for hepatitis... (the price depends on the season), 15 (MXN pesos; 0.73 USD) considering the season..." ... marrubio for gastritis...estafiate and fennel are good for stomach ache... (how much are they?) 15 MXN pesos (0.73 USD), any of them..." [P/R 8]. All of the uses mentioned by the harvesters (Table 2) are part of their sales pitches.

Rural poverty often leads to desperate survival strategies in the attempt to meet basic needs in the short term, while sustainability is long term. Therefore, there should be a revaluation of agriculture within the national economy, favoring strategies such as international trade reform, regional economic integration and urbanization that would lead to the relocation of agriculture and a restructuring of agricultural production (Gutiérrez et al., 2008).

\section{Use and consumption of endemic plants and medicinal properties}

Older adults (consumers) mentioned the use of 61 species of medicinal plants. Of these, 35 are purchased in the Ozumba tianguis with the collectors and producers, five are purchased in naturist stores, six are ornamental plants, two are catalogued as wild perennials and 13 are used as ingredients in regional cuisine and are attributed some medicinal property, which is why they are appreciated twice as much (Table 2).

The World Health Organization (2019) mentioned that 20 to $39 \%$ of the population in Mexico practices and uses herbalism and that foods which have functional properties can be included in this category.

Older adults also perform the harvesting activity because some medicinal plants are found at the edge of the sidewalks and in neglected gardens (wild 
estas, 35 se compran en el tianguis de Ozumba con los recolectores productores, cinco adquiridas en comercios naturistas, seis son plantas de ornato, dos se catalogan como perennes silvestres y 13 se utilizan como ingredientes de la cocina regional y se les atribuye alguna característica medicinal, por lo cual son apreciadas al doble (Cuadro 2).

La Organización Mundial de la Salud (2019) mencionó que del 20 al 39\% de la población en México practica y usa la herbolaria y que los alimentos que tienen propiedades funcionales pueden incluirse en esta categoría.

Los adultos mayores también realizan la actividad de recolección debido a que algunas plantas medicinales las encuentran a orillas de las banquetas y en jardines descuidados (perennes silvestres), tales como Lengua de vaca (Rumex crispus), Santa María (Tanacetum balsamita) y Té de monte (Satureja macrostema).

Las plantas medicinales mencionadas y utilizadas con mayor frecuencia por los adultos mayores fueron: ajo (Allium sativum) como antitusivo y anticancerígeno, manzanilla (Chamaemelum nobile) como antiinflamatorio ocular, prodigiosa (Brickellia cavanillesii) para los "corajes", árnica (Heterotheca inuloides) como hipotensor, antiinflamatorio ocular y enfermedades renales, epazote de zorrillo (Chenopodium graveolens) como antiparasitario y antihelmíntico, ajenjo (Artemisia absinthium) como hipoglucemiante y para los "enojos", hierbabuena (Mentha spicata) como hipoglucemiante y, por último, ruda (Ruta graveolens) en compresas para la cefalea, antiparasitario y para los "corajes".

En su mayoría, las plantas medicinales mencionadas por los adultos mayores son endémicas de la zona oriente del estado de México, como la prodigiosa (Brickellia cavanillesii) "...para los corajes hasta cuando lo toma una persona que hizo coraje con la prodigiosa..." [AM 3], "...con la prodigiosa hacen copita..." [AM 4] y "...yo lo he tomado pero asi sin alcohol..." [AM 5], el epazote de zorrillo (Chenopodium graveolens) "...el epazote para las amibas..." [AM 10], “...para los parásitos...” [AM 17], “...el epazote logra sacar las solitarias..." [AM 19], “...el té de epazote con hierbabuena..."[AM 26], y el ajenjo (Artemisia absinthium) "...el ajenjo es bueno porque es amargo y corta lo del azúcar...” [AM 16], “...el ajenjo es muy bueno es amargoso en ayunas también..." [AM 24], "...pero el ajenjo, es más amargo..." [AM 32], teniendo referencias ancestrales por los beneficios ali- perennials), such as "Cow's tongue" (Rumex crispus), Santa Maria (Tanacetum balsamita) and Mountain tea (Satureja macrostema).

The above mentioned medicinal plants and the most frequently used by the elders were garlic (Allium sativum) as antitussive and anticarcinogenic, chamomile (Chamaemelum nobile) as ocular antiinflammatory; Miraculous (prodigiosa) (Brickellia cavanillesii) for "anger distress"; Arnica (Heterotheca inuloides) as hypotensive, ocular anti-inflammatory and for renal diseases; skunk Epazote (Chenopodium graveolens) as antiparasitic and anthelmintic; Absinthe (Artemisia absinthium) as hypoglycemic and for "anger distress"; Mint (Mentha spicata) as hypoglycemic; and finally Rue (Ruta graveolens) in pads for headache, antiparasitic and for "anger distress".

Most of the medicinal plants mentioned by the older adults are endemic to the eastern part of the State of Mexico, such as the prodigiosa Miraculous (Brickellia cavanillesii) "...it's good for people with anger distress...". [AM 3], "...they use it to prepare drinks..." [AM 4] and "...I have taken it but without alcohol..." AM 5], the skunk epazote (Chenopodium graveolens) "...the epazote for the amoebas..." [AM 10], "...for parasites..." [AM 17], "...the epazote manages to get Taenia solium out..." [AM 19], “...epazote tea with mint..." [AM 26], and absinthe (Artemisia absinthium) "...absinthe is good because it is bitter and cuts sugar blood content..." [AM 16], "... absinthe is very good, it is bitter, and it is also good for fasting..." [AM 24], "...but it is more bitter..." [AM 32]. They have ancestral references for the food and medicinal benefits that the plant provides to the improvement of various symptoms of some diseases.

The older adults mentioned that the use and consumption of medicinal plants (Table 2) goes back to their grandparents who regularly performed such herbalism practices "...my grandmother was a revolutionary and they would take care of themselves on the road with what they found in the open field, she was a nurse and they used that a lot...". I remember when a child had a fever, my mother would put a "cow's tongue" leave with butter on the soles of feet and belly. [AM 10], "...my dad lived 99 years and always took absinthe..." [AM 11].

Some other examples of how they passed on the knowledge are mentioned in their speeches: "... I have learned what people have told me, and my 
mentarios y medicinales que aporta la planta en el mejoramiento de diversas sintomatologías propias de algunas enfermedades.

Los adultos mayores mencionaron que el uso y consumo de las plantas medicinales (Cuadro 2) se remonta desde sus abuelos quienes realizaban de forma habitual dichas prácticas de herbolaria "...mi abuela fue revolucionaria y ellas en el camino se atendían con lo que encontraban en el campo abierto y agarraban asi $y$ era enfermera y utilizaban mucho eso...” [AM 2], “... yo me acuerdo que mi mamá cuando tenía calentura algún niño le ponian la lengua de vaca con manteca en las plantas de los pies y en la panza...” [AM 10], “... mi papá dilató (vivió) 99 años y siempre tomo ajenjo..." [AM 11].

Algunos otros ejemplos de cómo les trasmitieron el conocimiento, lo mencionan en sus discursos "... yo he aprendido porque la gente me ha dicho y mi suegra era de Michoacán y más o menos yo veía los remedios..." [AM 17], "...es lo que nuestros padres nos inculcaron según ellos sus remedios caseros y todo..." [AM 21], "... a mi me daba mucha tos, hace rato me acordaba que mi hermana me cocía gordolobo con eucalipto y unos dientes de ajo..." [AM 9], “...mi suegra les hacia un té de manzanilla, hinojo, este cedrón y le digo que hay una hierba que parece la verdolaga que se da en la calle, no me acuerdo como se llama ..." [AM 13].

Los adultos mayores mencionan que ellos inten$\tan$ transmitir el conocimiento, pero encuentran resistencia de las nuevas generaciones a usar las plantas medicinales: "...le voy a llegar a decir a mi hija hazme un atole de masa y me va a decir prepáralo tú..." [AM 30], "...más que nada es otra generación por ejemplo nosotros le decimos a la nuera hazle tecito de este, si nomás dicen que sí, pero no se lo hacen..." [AM 2], aunque se presentan excepciones "... tengo mi nuera, que toma mucho té de abango, yo ese ni lo conocía. Para que no les dé gripa, como preventivo o ya que la tienen, luego oigo mi niño que dice mi mama me dio té de abango..." [AM 24].

El uso de la herbolaria está presente en la idiosincrasia de los mexicanos como demuestran estudios realizados en estados de México como Guerrero (Urióstegui-Flores, 2015), Nuevo León (GonzálezYánez et al., 2019), Veracruz (Lara-Reimers et al., 2019), Tabasco (Villarreal-Ibarra et al., 2014; Álvarez-Quiroz et al., 2017), Jalisco (García de Alba et al., 2012), y Ciudad de México (Mata et al., 2019). mother-in-law was from Michoacan and I knew more or less the remedies she knew...". [AM 17], "...it's what our parents instilled in us; their home remedies and everything..." [AM 21], "...I used to have coughs all the time, I remember my sister cooking me mullein with eucalyptus and some garlic cloves...” [AM 9], “... my mother-in-law made them chamomile, fennel, and cedar tea, and as I told you, there is an herb that looks like purslane and grows in the street, but can't remember its name... [AM 13].

Older adults mention that they try to pass on the knowledge but encounter resistance from the new generations to use the medicinal plants: “...I'm going to tell my daughter to make me a maize atole and she's going to tell me: prepare it yourself...”. [AM 30], “... it's another generation, for example, we tell my daughterin-law to make that tea, and she say yes, but she does not do it..." There are also some exceptions, "...I have my daughter-in-law, who drinks a lot of abango tea, which I didn't even know, and it serves to avoid flu, as a preventive, or it's good to drink once they have it, and then I hear my grand-child say: my mother gave me abango tea..." [AM 24].

The use of herbalism is always present in the idiosyncrasy of Mexicans, as shown by studies conducted in Mexican states such as Guerrero (Urióstegui-Flores, 2015), Nuevo Leon (GonzalezYáñez et al., 2019), Veracruz (Lara-Reimers et al., 2019), Tabasco (Villarreal-Ibarra et al., 2014; Álvarez-Quiroz et al., 2017), Jalisco (García de Alba et al., 2012), and Mexico City (Mata et al., 2019).

The infusion of leaves, flowers, fruits, roots or stems of medicinal plants, commonly called "tea", is the usual method of preparation, "...you pour a little bunch to boil and then drink it..." [AM 1], "... the flower and its calabash are boiled..." [AM 5], “... the boiled chamomile soaks in well so that it no longer has little petals..." [AM 16]. This form of preparation is not exclusive for ingesting, it is also useful as antiinflammatory, to wash eyes, and wounds in some part of the body through the elaboration of poultices "...boil as tea, strain it and put some drops in a clean rag in case of infection (wounds)...”. [AM 37], “...to wash out varicose veins..." (anti-inflammatory) [AM 15].

Herbal baths are common to relax and take advantage of the medicinal properties of plants, because some are given the characteristic of "hot effect" which is related to the anti-inflammatory 
La infusión de hojas, flores, frutos, raíces o tallos de plantas medicinales, en lo común llamado "té", es el método habitual de preparación, "...echa usted un manojito a hervir y ya luego se toma..." [AM 1], “... se pone a hervir la flor y su calabazo..." [AM 5], “...la manzanilla hervida nada más como tecito se cuela bien que no tenga ya petalitos..." [AM 16]. Esta forma de preparación no es exclusiva para ingerir también es útil como antiinflamatorio, para lavar ojos y heridas en alguna parte del cuerpo mediante la elaboración de cataplasmas "... hervida como tecito, colarla y en un trapo limpio echarle unas gotas y esa para cuando le da una infección (heridas)...” [AM 37], “...para lavar las venas varicosas..." (antiinflamatorio) [AM 15].

Los baños de hierbas son habituales para relajar y aprovechar las propiedades medicinales de las plantas, debido a que a algunas se les otorga la característica de "calientes" lo que se relaciona con la capacidad desinflamatoria debido a los componentes bioactivos contenidos en la planta "...cuando se baña uno con agua de hierbas hierba del ángel, este, jarilla, la ruda, el romero, albahaca, Santa María...” [AM 33], “... se pone a hervir si tienes un bracerito lo pones y cuando empiece la vaporización con una sábana o una toalla..." [AM 26], "...si hasta ahorita se sigue usando darles baños (a personas con fiebre) con esa, tibio para que reaccione..." [AM 8].

Los parches o rodajas muy pequeñas elaboradas de diversas plantas que se adhieren a las sienes se les conoce como "chiqueadores" "...de papa, de haba, se ponen para el dolor de cabeza..." [AM 4], "...yo en mis tiempos usaba, las habitas se ponían en las sienes..." [AM 4], en la actualidad la medicina alópata tiene mejor aceptación por la rapidez de efecto en el padecimiento.

La diversidad de plantas medicinales y los usos que reportan los adultos mayores responde a tres puntos: el primero es la ubicación geográfica de los municipios, el segundo es la perpetuación del conocimiento por medio de la comunicación oral, y el tercero es la forma de aplicación de la herbolaria para el tratamiento de algunas enfermedades. La sustentabilidad para los adultos mayores se construye como parte de una forma de conciencia ecológica y social aplicada en la cultura del cuidado de la vida (Toledo y Ortiz-Espejel, 2014). capacity due to the bioactive components contained in the plant "...when one bathes with water from angel's grass, this one; and jarilla, rue, rosemary, basil, Santa Maria...”. [AM 33], “...you put the herbs to boil in a firewood stove (brasero) and when the vaporization begins, you put a sheet or a towel cover your head and breathe...” [AM 26], “...up to now they still give baths with that one (to people with fever), it has to be warm for them to react...". [AM 8].

The very small patches or slices made from various plants that adhere to the temples are known as "chiqueadores" "...made of potato, from bean, they are used for headaches..." [AM 4], "...back in my time I used them, the beans were put in the temples..." [AM 4]. Currently, allopathic medicine is better accepted because of the rapid effect on the condition.

The diversity of medicinal plants and the uses reported by the elders respond to three points: the first is the geographical location of the municipalities, the second is the perpetuation of knowledge through oral communication, and the third is the application form of herbal medicine for the treatment of some diseases. Sustainability for elders is built as part of a form of ecological and social awareness applied to life caring culture (Toledo and Ortiz-Espejel, 2014).

\section{CONCLUSIONS}

Herbalism in the eastern part of the State of Mexico presents diverse agro-ecological, socioterritorial and economic interactions, and for these reasons it is a sustainable practice. The process of collection and production is linked to the agroecosystem; producers have knowledge acquired by generations and empiricism. This knowledge may be at risk because some is being lost, the intergenerational transmissibility decreases and consequently the future of the activity decreases. Other risks are of economic nature due to low prices; despite this, the actors identify themselves as guardians of knowledge with the obligation to disseminate this practice.

In relation to the consumer, the transmission of knowledge is limited to a suggestion, because it is not always carried out by the receiver. The continuity of use in cases and the intensity in which it occurs in the three municipalities studied leads us to still 


\section{CONCLUSIONES}

La herbolaria en la zona oriente del estado de México presenta interacciones agroecológicas, socioterritoriales y económicas diversas, y por tales motivos es una práctica sustentable. El proceso de recolección y producción está ligado al agroecosistema, los productores tienen conocimientos adquiridos por generaciones y empirismo. Estos saberes pueden estar en riesgo porque algunos se están perdiendo, la transmisibilidad intergeneracional disminuye y en consecuencia el futuro de la actividad también. Otros riesgos son económicos debido a los bajos precios; a pesar de esto, los actores se identifican como guardianes del conocimiento con la obligación de difundir esta práctica.

En relación con el consumidor, la transmisión del conocimiento se limita a una sugerencia, porque no siempre se lleva a la práctica por parte del receptor. La continuidad de los casos de uso y la intensidad en la que ocurre en los tres municipios estudiados lleva a considerar a la herbolaria todavía como una práctica sustentable. Los actores involucrados en la cadena de producción de plantas medicinales no son del todo conscientes de que su diálogo de saberes permanente, la inclusión de valores, cosmovisiones e identidades de su cultura local, y la transmisión intergeneracional de las prácticas agroecológicas, socio-territoriales y económicas que realizan, ha permitido conservar el equilibrio frágil de la producción de plantas medicinales de la zona.

\section{LITERATURA CITADA}

Altieri M., y V. M. Toledo. 2010. La revolución agroecológica de América Latina: rescatar la naturaleza, asegurar la soberanía alimentaria y empoderar al campesino. El Otro Derecho 42: 163-202.

Álvarez-Quiroz V., L. Caso-Barrera, M. Aliphat-Fernández, y Á. Galmiche-Tejeda. 2017. Plantas medicinales con propiedades frías y calientes en la cultura Zoque de Ayapa, Tabasco, México. Bol. Latinoam. Caribe Plantas Medic. Aromát. 16: 428-454.

Andrade-Cetto A., and M. Heinrich. 2005. Mexican plants with hypoglycaemic effect used in the treatment of diabetes. J. Ethnopharmacol. 99: 325-348.

Astier M. Argueta J., Q. Orozco-Ramírez, M. González, V. Morales, J. Gerritsen P., and R. Sánchez-Sánchez. 2017. Back to the roots: understanding current agroecological movement, science, and practice in Mexico. Agroecol. Sustain. Food Syst. 41: 329-348.

Chen S., L., H. Yu, M. Luo H., Q. Wu, F. Li C., and A. Steinmetz. 2016. Conservation and sustainable use of medicinal consider herbalism as a sustainable practice. The social actors involved in the chain of production of medicinal plants are not fully aware that their permanent dialogue of knowledge, inclusion of values, idiosyncrasy and identities of their local culture, and the intergenerational transmission of the agro-ecological, socio-territorial and economic practices that all of them carry out, have allowed them to preserve the fragile balance of the production of medicinal plants in the area.

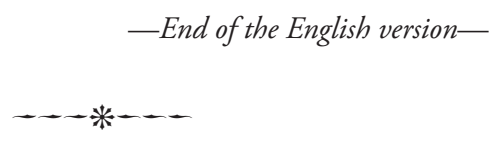

plants: problems, progress, and prospects. Chinese Med. 11: $1-10$.

Cussy-Poma V., E. Fernández, J. Rondevaldova, H. Foffová, and D. Russo. 2017. Ethnobotanical inventory of medicinal plants used in the Qampaya District, Bolivia. Bol. Latinoam. Caribe Plantas Medic. Aromát. 16: 68-77.

FAO (Organización de las Naciones Unidas para la Alimentación y la Agricultura). 2019. Los 10 elementos de la agroecología. Food and Agric. Org. Series pp: 1-15.

Fernandes P., and P. Boff. 2017. Medicinal plants in the family farms of rural areas in southern Brazil: ecological and ethnobotanical aspects. Bol. Latinoam. Caribe Plantas Medic. Aromáticas. 16: 493-505.

García de Alba, García J., E. Ramírez Hernández B. C., G. Robles Arellano, J. Zañudo Hernández, L. Salcedo Rocha A., y E. García de Alba Verduzco J. 2012. Conocimiento y uso de las plantas medicinales en la zona metropolitana de Guadalajara. Desacatos. 39: 29-44.

Gobierno del Estado de México. 2017. Plan de Desarrollo. Región I Amecameca Programa Regional 2011-2017. pp: 5557.

González-Yáñez, M. G., C. Rivas-Morales, M. A. Oranday-Cárdenas, M. J. Verde-Star, M. A. Núñez-González, E. Sánchez, and C. Leos-Rivas. 2019. Safety of aqueous extract of Calea ternifolia used in Mexican traditional medicine. EvidenceBased Complementary and Alternative Medicine. 2019: 1-7.

Gudynas, E. 2004. Ecología, Economía y Ética del Desarrollo Sostenible, 5ta. edición revisada, Editorial Coscoroba, Montevideo, Uruguay. 257 p.

Gutiérrez C., J., G. Aguilera Gómez L. I., y E. González Esquivel C. 2008. Agroecología y sustentabilidad. Convergencia. 46: 51-87.

Hernández-Xolocotzi, E. 1985. Xolocotzia: Obras de Efraím Hernández Xolocotzi. Tomo 1. Revista de Geografía Agrícola. Universidad Autónoma de Chapingo, Texcoco, México. $527 \mathrm{p}$. 
Lara-Reimers, E. A., D. J. Lara Reimers, P. Chaloupkova, J. M. Zepeda del Valle, L. Milella, and D. Russo. 2019. An ethnobotanical survey of medicinal plants used in Papantla, Veracruz, Mexico. Plants. 8: 1-20.

Leff E. 2004. Racionalidad Ambiental: la Reapropiación Social de la Naturaleza. México. Siglo XXI. 509 p.

Linares E., y R. Bye. 2009. La dinámica de un mercado periférico de plantas medicinales en México: el tianguis de Ozumba, Estado de México, como centro acopiador para el mercado de Sonora (mercado central). Históricas Digital. Serie Historia General. Caminos y mercados de México. UNAMINAH. 23: 631-664.

López L., V., M. 2008. Sustentabilidad y Desarrollo Sustentable. México: Trillas. 202 p.

Martin G., J. 2004. Ethnobotany: a methods manual (Vol. 1) Springer. US. pp: 8-25.

Martínez G., J. 2005. Recolección y comercialización de plantas medicinales en el departamento Santa María, provincia de Córdoba, Argentina. Acta Farmac. Bonaer. 24: 575-584.

Mata, R., M. Figueroa, A. Navarrete, and I. Rivero-Cruz. 2019. Chemistry and biology of selected mexican medicinal plants. In: Progress in the Chemistry of Organic Natural Products 108. Kinghorn A., H. Falk, S. Gibbons, J. Kobayashi, Y. Asakawa, and J. K. Liu (eds). Springer, Cham. pp: 1-142
OMS (Organización Mundial de la Salud). 2013. Estrategia de la OMS sobre Medicina Tradicional 2014-2023. Ginebra, Suiza. 75 p.

OMS (Organización Mundial de la Salud). 2019. WHO Global Report on Traditional and complementary Medicine 2019. World Health Organization. 226 p.

Parthiban R., S. Vijayakumar, S. Prabhu, and E. M. Yabesh J. G. 2016. Quantitative traditional knowledge of medicinal plants used to treat livestock diseases from Kudavasal taluk of Thiruvarur district, Tamil Nadu, India. Ver. Bras. Farmacog. 26: $109-121$

Toledo V., y B. Ortiz-Espejel. 2014. México, Regiones que caminan hacia la Sustentabilidad: Una Geopolítica de las Resistencias Bioculturales. Universidad Iberoamericana Puebla. 146 p.

Toledo V., M., 2002. Agroecología, sustentabilidad y reforma agraria: la superioridad de la pequeña producción familiar. Agroecologia e Desenvolvimento Rural Sustentável. 3: 2736.

Urióstegui-Flores A. 2015. Hierbas medicinales utilizadas en la atención de enfermedades del sistema digestivo en la ciudad de Taxco, Guerrero, México. Rev. Salud Pública. 17: 85-96.

Villarreal-Ibarra E., C. García-López E. López P., A. PalmaLópez D., J. Lagunes-Espinoza L., D., C. Ortiz-García C., y F. Oranday-Cárdenas A. 2014. Plantas útiles en la medicina tradicional de Malpasito-Huimanguillo, Tabasco, México. Polibotánica. 37: 109-134. 